\title{
Activity Patterns of Zapus princeps Prior to Hibernation
}

\author{
WZORZEC AKTYWNOSCI U ZAPUS PRINCEPS PRZED HIBERNACJA
}

\section{Lucius L. STEBBINS}

Stebbins L. L., 1983: Activity patterns of Zapus princeps prior to hibernation. Acta theriol., 28, 20: 321-323 [With 1 Fig.]

Activity of Zapus princeps Allen, 1899 was studied in late summer. The animals showed a well defined, nocturnal pattern of activity with occasional short bursts of activity in daylight hours. Amount of activity gradually decreased over the 4 days prior to commencement of hibernation.

[Dept. of Biological Sciences, University of Lethbridge, Lethbridge, Alberta, Canada T1K 3M4]

\section{INTRODUCTION}

Activity of two male jumping mice, Zapus princeps Allen, 1899 captured near Lethbridge, Alberta, Canada, $49^{\circ} 72^{\prime} \mathrm{N}, 112^{\circ} 49^{\prime} \mathrm{W}$, was studied in August, and September, 1968. No previous studies of activity of this species have been reported though field observations of capture times indicate nocturnal habits of this and all closely related species. Several previous personal attempts to raise and study this species in captivity have always resulted in the animals entering into hibernation within a day or two of capture and dying soon trereafter. For some reason unknown this did not happen with these two males. This behavior does explain the small sample size and short duration of the study. Purpose of this study was to describe the daily pattern of activity of this species.

\section{METHODS}

A male was captured on July 28, 1968 and placed in a cage of dimensions $45 \mathrm{~cm} \times 45 \mathrm{~cm} \times 60 \mathrm{~cm}$ with a nest box of dimensions $8 \mathrm{~cm} \times 8 \mathrm{~cm} \times 18 \mathrm{~cm}$ with terylene fiber for nesting material. Sunflower seeds were supplied ad libitum in a small wire mesh box connected to the cage by a wire mesh tunnel. One activity switch, a swinging door attached to a mercury switch operating a pen on a Esterline Angus even recorder, was in the tunnel leading to the food store. A second similar switch was in a tunnel attached to the nest box. Each passage in either direction was recorded as a single stroke of the pen on the chart paper. A second male was captured on August 21 and added to the same cage and nested in the same nest box as the first. Activity was recorded from July 29 until both animals entered hibernation on September 11, 1968. The test animals and switching mechanisms were left undisturbed until November 6, 1968.

The cage was placed on the ground in a semi-natural enclosure near Lethbridge and shielded by a 2 meter high wooden fence and shrubbery. No other protection was given. Range of daily mean minimum temperatures during the experimental period was from $+10^{\circ} \mathrm{C}$ to $+5^{\circ} \mathrm{C}$, range of mean daily maximum temperatures was $+16^{\circ} \mathrm{C}$ to $+23^{\circ} \mathrm{C}$. 


\section{RESULTS}

Activity, measured as passages through the gate at the entrance to the nest box, and as passages through the entrance to the food box is shown in Fig. 1.

The test animals were basically nocturnal throughout the study with occasional short bursts of activity in daylight hours. Commencement and cessation of activity closely followed sunset and sunrise. Most activity seems to have been at the food supply, presumably gathering seeds for storage, as the animals stored seeds in their nest each night.

After about the 4 th or 5 th of September activity gradually declined until it ceased altogether on September 11. One animal was first seen hibernating on September 9 and the second on September 11. Neither

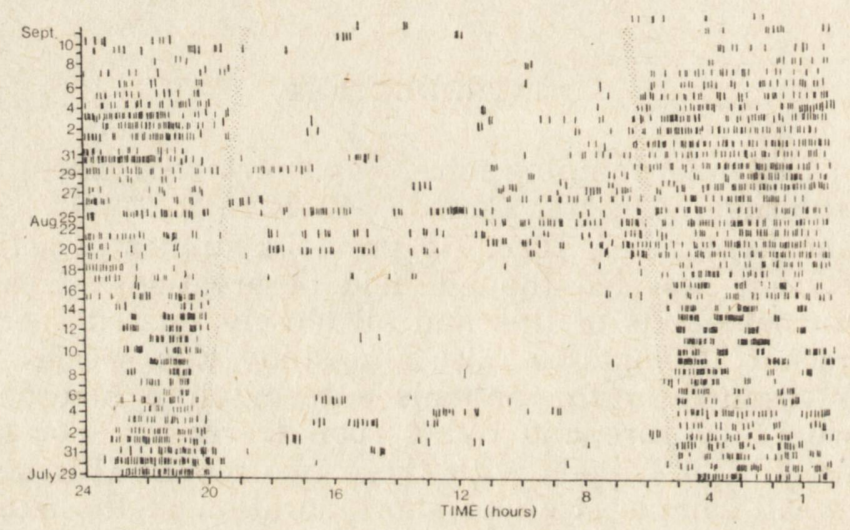

Fig. 1. A transcript of the original chart paper showing activity of Zapus princeps out the nest box and at the food box between July 29 and September 11, 1968. Stipled area indicates approximate time of sunrise and sunset. Time is given with hour 0100 through 2400 abbreviated to hour 1 through 24.

animal became active again for the next 47 days, after which the experiment was terminated. The animals, still in hibernation, weighed 26.0 and 27.2 gms respectively on November 6, 1968.

\section{DISCUSSION}

Circadian rhythms of activity of this species have not been previously reported though these data agree with a published observation of field captures of Zapus spp. and Napeozapus sp. (Soper, 1964) in which Zapus princeps was captured chiefly at night but occasionally observed abroad in daytime. Similar observations have been reported for other species; N. insignis by Sheldon (1934), Hamilton (1935), Brower \& Cade (1966), and Z. hudsonius by Sheldon (1934), Quimby (1951), Whitaker (1963). Activity of unrestrained $Z$. hudsonius and $N$. insignis, as determined by tracks in a sand transect, also showed daily peak of activity to occur at night (Bider, 1968). In addition, though activity was not recorded, 
the same basic pattern was suggested for caged Z. hudsonius by Quimby (1951) and Sheldon (1934) and supported by observations of a daily rhythm of changes in body temperature by Morrison \& Ryser (1962). A basically similar pattern of activity was also reported for the closely related species, Sicista betulina (Erkinaro, 1972).

\title{
REFERENCES
}

Bider R., 1968: Animal activity in uncontrolled terrestrial communities as determined by a sand transect technique. Ecol. Monogr. 38: 269-308. - Brower J. E. \& Cade T. J., 1966: Ecology and physiology of Napeozapus insignis (Miller) and other woodland mice. Ecology, 47: 47-63. - Erkinaro E., 1972: Phase shift of locomotory activity in a birch mouse, Sicista betulina, before hibernation. J. Zool. Soc. London, 168: 433-438. - Hamilton W. J., 1935: Habits of jumping mice. Amer. Midl. Natur., 16: 187-200. - Morrison P. \& Ryser F. A., 1962: Metabolism and body temperature in a small hibernator, the meadow jumping mouse, Zapus hudsonius. J. Cell. and Comp. Physiol., 60: 169-180. - Quimby D. C., 1951: The life history and ecology of the meadow jumping mouse, Zapus hudsonius. Ecol. Monogr., 21: 61-95. - Sheldon C., 1934: Studies on the life histories of Zapus and Napeozapus in Nova Scotia. J. Mammal., 15: 290-300. - Soper J. D., 1964: The mammals of Alberta. Hamly Press: 1-402. Edmonton, Alberta. - Whitaker J. O., 1963: A study of the meadow jumping mouse, Zapus hudsonius (Zimmerman), in central New York. Ecol. Monogr., 33: 215-254.

Accepted, February 23, 1983.

\section{The Significance of Bait and Camouflage on Longworth Trapping of the Wood Mouse}

\author{
WPEYW PRZYNETY I SPOSOBU USTAWIANIA PUEAPKI \\ NA ŁOWNOSC MYSZY ZAROSLOWEJ
}

\section{Graham M. BATHE}

Bathe G. M., 1983: The significance of bait and camouflage on Longworth trapping of the wood mouse. Acta theriol., 28, 20: 323-327 [With 2 Tables \& 2 Figs.]

A comparison was made between the number of Apodemus caught with a) untreated, b) baited, c) camouflaged, and d) baited and camouflaged Longworth traps. The results showed that external bait increased trap occupation during the 20-day study period, but camouflage increased occupation during the first 10 days only. Traps both baited and camouflaged consistently obtained the highest catches. The results are interpreted in relation to the know behaviour of rodents towards traps.

[Dept. of Biological, Sciences, University of Exeter, Prince of Wales Road, Exeter, England, UK]. 